\title{
Three Dimension Movie for the Students' Ability in Narrative Writing
}

\author{
FITA FARIDAH \\ Fakultas Teknik, Universitas Islam Lamongan \\ Email address: pitaparidah@gmail.com
}

\begin{abstract}
:
This present study is conducted in order to improve the students' writing narrative text by using Three Dimension Movie. It has several steps the first is Pre-writing In this phase the teacher combined with writing process included: planning and drafting. The second is Whilst-writing activities, in this phase the teacher combined with writing process include: revising and editing and the third is Post-writing activities, post-writing tasks allow for reflection, sharing, or publishing of the final product. This study employed Classroom Action Research (CAR) as the research design. The procedure of the research involved four stages: planning the action, implementing, observing, and reflecting. Using three dimension movie is intended the students deep understood the story of movie. Second, the technique used was found effective to make the group focus during writing process. Related to the students' ability in writing narrative text, this strategy is very helpful to the students to build ideas to write and inspired them with adventurous imagination. The use of three dimension movie as the visual media in teaching and learning process especially in writing narrative text is intended to stimulate the students and support the teaching and learning activities more effective, efficient, interesting and valuable so that the quality of learning can be improved.
\end{abstract}

Key words: writing narrative text, three demension movie, and classroom action research

\section{Introduction}

Writing is one of the four language skills that are very important to learn, it has given an important contribution to human work. Writing as a process to get product is influenced by some elements such as vocabularies, grammar, organizations, punctuation, spelling and mechanics. writing is a complex activity that is form process as a way gets things done and product as the result. Nunan (2003) explains that writing is a combination of process and product. The process means the act of gathering ideas and working with the students until they are presented a polished and comprehensible result to the readers. Lindsay and Knight (2006) stated that writing is putting together the letters into form of words, phrase, clauses, and sentences in making a coherent text.

The process of writing is a technical document to produce a written text. According to Singh (1994) writing performs at three stages: Pre-writing, 
Writing, and Post-writing. In pre-writing activity, the students are asked to have the planning of what they are going to write. The students need to consider the purpose (what they expect to achieve through their writing) and the constraint (personal, material, system, time, etc.) in Writing activity, it starts about how to generate the ideas and to develop them into written structure, which mean the students convey concrete information into a draft. At last, Post-writing activity, this is the stage of reviews, re-read and evaluates the draft until they get the final draft.

Writing skill is considered as one of the aspects of a language that is difficult to master by students. There are many problems faced, and one of them is the organization of thoughts and ideas. This is one of the many reasons why a teacher should teach the right way in order that students can organize their ideas into written form.

Based on the researcher's observation at the Vocational High School the researcher found some problems related to the English language teaching and learning in this school. Those problems are: 1) the students have low writing ability especially in narrative text. 2) The students have low motivation in learning English; and 3) the teacher still uses monotonous and inappropriate teaching techniques. Considering the problems that are faced by the teacher above, it can be said that the English teachers still meet some serious problems in teaching and learning process. Those three problems are very close connected and correlate one another. The monotonous and inappropriate teaching technique used by the teacher might cause low motivation on the students in learning English which affect their ability in writing. The students soon get bored and uninterested in learning when they are always exposed to the monotonous instructional activities; and therefore, they do not participate actively. This teaching and learning process happen even though the students are not showing their interest in this kind of classroom activity.

So, it can be said that the root of the three problems above is the monotonous and inappropriate teaching technique or media used by the teacher. Hence, it needs to propose the appropriate technique to overcome the students"e low writing ability. It is the responsibility of the teacher to find out the effective media for presenting the materials in order to stimulate the studentse positive attitude toward the writing class (Burns \& Joice,1997:10). In teaching and learning process, teacher needs media to make the lesson easier. Teaching learning process should be varied to make students feel fun during the process. They need more than instruction and commandment from their teacher. It is teachers' challenge to be able to motivate the students to pay attention in their lesson. So, teacher needs media in language learning. Media can bring and arouse students' happiness and renew their spirit in studying. It also can help the students in placing their knowledge to their mind and rekindle the lesson. Media is one of forms of 
communication that is printed or audio visual.

There are many media that can be used by the teacher to motivate and improve students' speaking skill, and some of those techniques need media to help the teachers to apply it in more effective and easier way. According to Hamalik (1980:50-51), teaching media consist of several kinds, such as: (1) Supplementary materials including reading materials: book, comic, newspaper, magazine, bulletin, folder, pamphlet. (2) Audio visual media: (a) Non projector media; blackboard/ whiteboard, diagram, graphic, poster, cartoon, comic, picture. (b) Three dimension media; model/natural thing like diorama, doll, mask, map, globe, school museum. (c) Machined media; slides, filmstrip, film, record, radio, television, computer. (3) Society source: people, industry, history, area, custom, politic. (4) Material collection: chemist, seed, and leaves.(5) Gesture: all action by the teacher in the class like moving hands, foot, body, and facial expression.

Based on the statement above, one of the kinds of teaching media is audio visual media which consist of nonprojector media, three dimension media, and machined media. One example of machined media that can be used to teach is movie. In this case, the researcher as a teacher has to use appropriate, fun, and effective media in teaching and learning writing. One of media that can be used in teaching and learning writing is three dimension movie. Grenville (2001: 137) said that three dimension fulfills the characteristics of good media. Three dimension movie lead the students put up with vocabulary. It also motivates the students to use the language since it tells us the current events and presented in a funny way so that the students find themselves easy to express the message in written form.

Based on the problem that has been stated above, the researcher formulates the problem of the study is as follows: How can three demension movie could be implemented to improve students' ability in writing narrative text?

Using three dimension movie as the means for helping the students to see and to understand how exactly the plot develops. It is due to the four reasons to have English language practice and acquisition, as follow: (1) three dimension movies are enjoyable, (2) three dimension movies are easily available everywhere, (2) the timeline of the movies can be arrange as desirable and (4) three dimension movies are serving the moral value of any condition of daily life, especially for students. Related to the students' ability in writing narrative text, this strategy is very helpful to the students to build ideas to write and inspired them with adventurous imagination. The use of three dimension movie as the visual media in teaching and learning process especially in writing narrative text is intended to stimulate the students and support the teaching and learning activities more effective, efficient, interesting and valuable so that the quality of learning can be improved. 


\section{Method}

This study was conducted at SMK Sunan Drajat Sugio Lamongan, This study focused on class $\mathrm{X}$ Electricity installation (ITL) at the second semester around April until Mei 2016. The research design that would be suitable to apply in this research is Classroom Action Research (CAR). According to Kemmis and Mc Taggart (1998) this action research was conducted through the following procedure: (1) preliminary study to know the real problem face the students, (2) planning, (3) implementing,

(3) observation, (5) reflection. And In collecting datathis research, the researcher took three ways. Those were test, observation and field note.In this research, the writer planned to conduct two

cycles of classroom action research. There are four steps process in every one cycle for doing classroom action research. Before implementing the three demension movie in narrative writing text, the researcher and collaborator designed lesson plan and the lesson plan

focused on the use of three demension movie in the student' narrative writing text. The researcher decided the criteria of success focused two aspects, the score of writing improvement in the achievement test in narrative writing text using three demension movie and learning process. The passing criterion that must be attained considering English writing which is 65 (sixty five). It is adapted from the school agreement in SMK Sunan Drajat Sugio Lamongan especially in the result of writing score.
The first step to improve the students' writing narrative text is preparation of the strategy. The researcher determined three demension movie as the suitable strategy to improve the students' writing ability in narrative text and the researcher used three phase technique include pre-writing, whilstwriting and post-writing activities combine with writing process strategy include planning, drafting, revising, editing and final draft.

\section{Pre-writing activities}

In this phase the teacher combined with writing process include: planning and drafting. The activities in planning such as the teacher build students' knowledge of relevant vocabulary, relevant grammar points and, most importantly, students' background knowledge, and the teacher explain generic structure of narrative text, and then the students watched the three demension movie. And the next activities were drafting, in this stage can be provided by the teacher or generated through brainstorming by the students. They can follow the Five Ws and the Hfrom the film: who, what, when, where, why and how). The teacher guide the students during them write the draft.

\section{Whilst-writing activities}

In this phase the teacher combined with writing process include: revising and editing. The students are ready to write, they need clear instructions and resources to complete the next steps in the process: Students should be allowed 
to use notes and draft they generated from the pre-writing tasks. The students will write a narrative text based on the three demension movie story. It will describe in some detail - the more interesting the better - what you did, where, and how it went. After the students are finished composing the short story, make sure to re-read the story and run through the self-editing checklist, before the final draft collected to the teacher.

\section{Post-writing activities}

Post-writing tasks allow for reflection, sharing, or publishing of the final product help learners reflect on and revise their writing based on feedback from the teacher.

During the teaching learning process, the researcher observed the implementation of the actions. The researcher acted as the English teacher who implemented the actions she was accompanied by collaborator as the observer. The observation would be recorded on observation checklist and taking notes.

In collecting data this research, the researcher took three ways. Those were test, observation and field note. The reflecting stage is the activity of analyzing the students' score in a writing test which is conducted in the end of each cycle of this research. In this stage, the researcher discussed and analyzed about how is the students' skill in writing narrative text after the strategy developed in this research implemented in the class and also discussed about the factors that might be caused of unsuccessful score got. The score data was compared to the indicators of the criteria of success.

\section{Result}

In Cycle 1 was done four meetings for teaching and learning process and conducting the test. The findings of the students' active involvement in the teaching process implementing three dimension movie in writing narrative text were the explanation of the students' involvement during the teaching learning process. Three points were considered as the strengths of the implementation of the strategy. They were enthusiastic to follow the teacher's explanation about narrative text. They could mention several example of narrative text. However, they still had difficulties to do the exercises in simple past. Moreover, they still had difficulties to understand the generic structure of the narrative text, the weaknesses in the cycle 1 are some groups did not share the idea they got from the three dimension movie and the pronunciation of the three dimension movie. There were some students did not understand the dialog, finally needed guiding by teacher more. This point was considered less effective by the observer since the goal of that meeting could not be completely achieved. The goal was the students were able to make a draft narrative text in group appropriately.

The writing test was administered to the students after the implementation of the strategy in the classroom in Cycle 1 consisting of four meeting. The type of test was writing narrative text test based 
the story of Kungfu panda "The Dragon Warrior" and the time was 90 minutes.

Based on the result of the test, it was found that average score indicated an improvement of students' writing narrative text compared to the score of 56.0 in the preliminary study (see appendix 2). In the preliminary study, there were 5 students $(25 \%)$ of 20 students in grade $X$ ITL who could pass or achieve the writing minimum score (KKM) of 65. This mean there were 15 students $(75 \%)$ of them who were still below KKM.

The fact was that after the implementation of three dimension movie in writing narrative text in Cycle 1 of four meetings. There were improvement of students' writing narrative text and the score was 62.1 and the table below shows the recapitulation improvement of students' achievement in writing narrative text from the preliminary study to the writing test after the implementation in Cycle 1. The table shows that, there were 7 out of 20 students (35\%) achieved the score 65 and above, 13 out of them (65\%) achieved the score below the KKM of 65 .

\begin{tabular}{|l|l|l|l|l|}
\hline \multirow{2}{*}{$\begin{array}{l}\text { Score } \\
\text { Range }\end{array}$} & \multicolumn{2}{|c|}{$\begin{array}{c}\text { Preliminary } \\
\text { study }\end{array}$} & \multicolumn{2}{c|}{ Cycle 1 } \\
\cline { 2 - 5 } & Freq & $\mathbf{( \% )}$ & Freq & $\mathbf{( \% )}$ \\
\hline $40-50$ & 7 & $35 \%$ & 3 & $15 \%$ \\
\hline $55-60$ & 9 & $45 \%$ & 10 & $50 \%$ \\
\hline $\begin{array}{l}>65 \\
(\text { KKM) }\end{array}$ & 4 & $20 \%$ & 7 & $35 \%$ \\
\hline Total & $\mathbf{2 0}$ & $\mathbf{1 0 0} \%$ & $\mathbf{2 0}$ & $\mathbf{1 0 0} \%$ \\
\hline
\end{tabular}

Table 1. Improvement of the students' Score in

Writing Narrative Text in Cycle 1
Even though most of the students, score were still under the minimum score (KKM), their score were improved to certain point. In details, the students' mean score for each aspect of writing in the writing test of cycle 1 is presented in the table below

\begin{tabular}{|l|l|l|l|}
\hline No & $\begin{array}{l}\text { Writing } \\
\text { Aspect }\end{array}$ & $\begin{array}{l}\text { Average } \\
\text { Score }\end{array}$ & $\begin{array}{l}\text { Maximum } \\
\text { Score }\end{array}$ \\
\hline 1 & Content & 6.25 & 9 \\
\hline 2 & Organization & 5.9 & 6 \\
\hline 3 & Vocabulary & 5.3 & 6 \\
\hline 4 & Grammar & 3.85 & 4.5 \\
\hline 5 & Mechanics & 3.55 & 4.5 \\
\hline $\begin{array}{l}\text { Average Score of } \\
\text { Writing Aspect }\end{array}$ & 24.85 & 30 \\
\hline
\end{tabular}

Table 2. The Average Score of Each Aspect of Writing in Cycle 1

This means that the teaching of writing narrative using three dimension movie in the first cycle had not made a significant improvement yet, mainly in terms of organization, grammar, vocabulary, and mechanics.Considering that the finding in Cycle 1 of the present study have not met all the criteria of success, the researcher and observer concluded that the action had to be continued to the next cycle.

Based on the result of the Cycle 1, the researcher found that less the guiding in the Cycle 1 made the result of the Cycle 1 not really satisfying, so the researcher made the revision of the strategy implemented in the Cycle 2, it was done four meetings for teaching and learning process and conducting the test. the teacher gave more explanation about generic structure of narrative text, simple past, vocabulary related with the cartoon 
and mechanics of narrative text. Start from the first meeting until the third meeting the teacher guiding the student in the process teaching writing narrative text using three dimension movie. The researcher as a teacher divided the students into five groups, this is intended to make it easier for teacher's guiding. Then teacher played three dimension movie. Then she played the movie using play and pause technique while she asked the student the story of the movie, the students were very enthusiastic.

In the writing test part two, the revision was made based on the observer suggestion, in writing test of Cycle 2 the researcher played the movie and then the researcher wrote the aspects of writing in the instruction to remind them to be more careful in writing in term of content, organization, grammar, vocabulary, and mechanics. The students also received a list of vocabulary items showing the key words in three dimension movie. Also the teacher wrote some questions based on the story to make it easier the students to write narrative text.

Better improvement of the students' individual and mean score from the preliminary writing test to the second writing test was apparent in Cycle 2. From 20 students who participated in the implementation of three dimension movie in writing narrative text, the researcher found that there was an improvement of the students who could reach the target score. Each of them already fulfilled the criteria of success. The writing test was administered to the students after the implementation of the strategy in the classroom in Cycle 1 consisting of four meeting. The type of test was writing narrative text test based the story of Kungfu Panda "The Special Holiday" and the time was 90 minutes.

Based on the result of the test, it was found that average score indicated an improvement of students' writing narrative text compared to the score of 62.1 in the Cycle 1 and 68.5 in Cycle 2. The fact was that after the implementation of three dimension movie in writing narrative text in Cycle 2 of four meeting. There were improvements of students' writing narrative text. The result was among 20 students, there were 16 students (70\%) who gained 10 points or more as their improvement in writing narrative text, whereas 4 students (20\%) had not achieved the minimum criteria yet. Tabel below shows the recapitulation improvement of students, achievement in writing narrative text from the Cycle 1 to the writing test after the implementation in Cycle 2.

\begin{tabular}{|l|l|l|l|l|}
\hline \multirow{2}{*}{$\begin{array}{l}\text { Score } \\
\text { Range }\end{array}$} & \multicolumn{2}{|l|}{ Cycle 1 } & \multicolumn{2}{l|}{ Cycle 2 } \\
\cline { 2 - 5 } & Freq & $\mathbf{( \% )}$ & Freq & $\mathbf{( \% )}$ \\
\hline $40-50$ & 3 & $15 \%$ & - & \\
\hline $55-60$ & 10 & $50 \%$ & 4 & $30 \%$ \\
\hline$>65(\mathrm{KKM})$ & 7 & $35 \%$ & 16 & $70 \%$ \\
\hline Total & $\mathbf{2 0}$ & $\mathbf{1 0 0} \%$ & $\mathbf{2 0}$ & $\mathbf{1 0 0} \%$ \\
\hline
\end{tabular}

Table 3. Improvement of the students' Score in Writing Narrative Text in Cycle 2

In details, the students' mean score for each aspect of writing in the writing test of Cycle 1 is presented in Table below: 


\begin{tabular}{|l|l|l|l|}
\hline No & \multicolumn{1}{|c|}{$\begin{array}{c}\text { Writing } \\
\text { Aspect }\end{array}$} & $\begin{array}{c}\text { Average } \\
\text { Score }\end{array}$ & $\begin{array}{c}\text { Maximum } \\
\text { Score }\end{array}$ \\
\hline 1 & Content & 6.85 & 9 \\
\hline 2 & Organization & 6.5 & 6 \\
\hline 3 & Vocabulary & 5.8 & 6 \\
\hline 4 & Grammar & 4.13 & 4.5 \\
\hline 5 & Mechanics & 4 & 4.5 \\
\hline $\begin{array}{l}\text { Average Score of } \\
\text { Writing Aspect }\end{array}$ & $\mathbf{2 7 . 2 8}$ & $\mathbf{3 0}$ \\
\hline
\end{tabular}

Table 4. The Average Score of Each Aspect of Writing in Cycle 2

Based on the result of the writing test at the end of cycle 2, the researcher could see that there was improvement on students writing in all aspect of writing especially in organization, vocabulary, grammar, and mechanics. The improvement of the students score had met the fourth criterion of the success. Thus, the researcher and the observer concluded that the action could be terminated. Based on the result of the writing test at the end of cycle 2, the researcher could see that there was improvement on students writing in all aspect of writing especially in organization, vocabulary, grammar, and mechanics.

\section{Discussion}

Based on the finding of the study, it was shown that the three demension movie an improved the students' ability in writing narrative text. According to Hyland (2013) stated that writing is a way to convey, express feeling and share writer's experiences to the reader by using written language. Writing skill includes some abilities, such as: 1) ability to write words, 2) ability to write sentences, 3) ability to write a paragraph, and 4) ability to compose along text. The students' improvement on each aspect was gained through the use of three demension movie and the teacher's guidance during the writing process.

To teach writing in the classroom the teacher used a media to help the students to get their idea. That is the reason why the researcher was interested applying three demension movie as her teaching media in teaching writing narrative text. According to Hirst (2013) argued that the use of cartoon is a motivational devices that works for English speakers as well as from whom English will be a second language. And Mufarrokah (2009) stated that applying the right media in teaching learning will improve students' learning outcomes.

The students very active follow the process of teaching writing narrative text using three demension movie and the improvement of students' active involvement in teaching writing narrative text had increased. The use of three demension movie made the students give full attention to the learning process. This affected their motivation and their learning of writing English well. Using three demension movie increase the students' motivation. Brown (2007:92) argued that a pleasant teaching style or strategy in the classroom can increase the students' motivation to learn. Not only the students' motivation had increased also the students' ability in writing narrative text after giving treatment using animated film in each cycle increased. 
The students' improvement on organization was obtained through the scenes of the movie that already represented the chronological order of the story which is considered as a significant part of narrative text. According to Brown (1983:294) stated that chronological order is way of organizing events in time order in which they take place. This study shows that three demension movie very helpful the students in writing story with appropriate organization since every event or generic structure of narrative text was set in correct order.

The next students' improvement on grammar, the students were assigned to change the form of verbs into past tense. The sentences used in the explanation session were related to the dialog in the three demension movie. The use of three demension movie also improve students' understanding vocabulary since the movie and the dialog cooperate with each other meaning that most of the expressions shown by the characters reflect the content of the dialog. This is line with Katchen (1995) who stated that animated cartoon film usually tell a simple story that is easy to follow.

This supported by Zulfadlan (2013) who stated that the use of animation movie is effective to improve students achievement in writing narrative paragraph, the students got improvement in writing narrative paragraph by using Animation Movie. Furthermore, the use of animated cartoon made the students give full attention to the learning process. This affected their motivation and their learning of writing English well. The condition of teaching and learning process dealing with the use of three demension movie was in line with Wittich and Schuller (1953:138), who stated that one of the strongest benefits of using three dimension movie to teach is ability to motivate students since it brings a cheerful atmosphere into the class. It is also supported by Akmala (2011) who stated that the use of animated film to improve students' ability in writing narrative text at senior high school. She showed that the strategy taught narrative using three dimension movie, could increase the students' writing ability in narrative text since it is interesting and motivating. It can motivate the students to learn English lesson especially in learning narrative text. Learning writing narrative text is not easy since the students did not know what they must write. Using three dimension movie can be a new atmosphere for the students who have not been taught using movie before.

From the explanations above, the researcher concludes that three demension movie can be a teaching medium to improve students' writing ability. According to Widarso, "one of good stimulus to get writing process easier for students is a set of questions which are related to each other. The implementation of three demension movie also could improve students' activities in teaching and learning process. 


\section{Conclusion}

Three demension movie can improve students' ability of class X ITL at SMK SUNAN DRAJAT SUGIO Lamongan in writing narrative text since it is interesting and motivating. It can motivate the students to learn English lesson especially in learning narrative text. Learning writing narrative text is not easy since the students did not know what they must write. Using three demension movie can be a new atmosphere for the students who have not been taught using three demension movie before. Watching three demension movie can be fun way to learn narrative text and how to produce or write narrative text. Teaching - learning understandable with choosing right and fun medium to teach narrative text can raise the students' mood to learn deeply about material. After the students motivate themselves to learn about material, it will raise their spirit to write something using their answer from the questions of film as guidance in learning writing process so that their writing ability improved. There are several important things that can be suggested in the last report of the paper and it is hopefully can be useful for the reader, especially for English teacher to use this medium in language classroom to teach writing or other skills in other genres. And Students are encouraged to watch programs and then write a narrative paragraph.

\section{References}

Akmala, 2011. The Use of Animated Film to Improve Students Ability in Writing Narrative Text. Unpublished thesis. Tarbiyah Faculty, walisongo State Institute for Islamic Studies Semarang.

Brown, H.D. 2007. Teaching by Princyple, An Interactive Approach to Language Pedagogy. United State of America: Pearson Education.Inc.

Burn, A and Joyce, H. 1997. Focus on Speaking. Sydney: Mcquire University Press.

Hamalik, Oemar. 1980. Sistem Pengelolaan Kelas: Manajemen Pendidikan. Bandung, Sinar Baru.

Hyland, K. 2013. Second Language writing. Cambridge: Cambridge University Press

Katchen. 1995. Cartoon For Writing Practice. Available at http://mx.nthv.edu.tw/Katchen/professional/cartoon.htm. accessed on April 2015

Kemmis, S and Mc Taggart, R. 1998. The Action Research Planner. Victoria: Deakin University Press.

Kemmis, S and Mc Taggart, R. 1998. The Action Research Planner. Victoria: Deakin University Press.

Lindsay, Cora and Paul Knight. 2006. Learning and Teaching English a Course for Teacher. New York: Oxford University Press.

Mufarrokah, A. 2009. Strategi Belajar Mengajar. Yogyakarta: Teras. 
Nunan, David. 2003. Practical English Language Teaching. New York: McGraw-Hill.

Singh, R.K. 1994. Interactional Process Approach to Teaching Writing. TESOL, Quarterly, vol 32. No.4. 18-

23.

Wittich, Walter Arno and Schuller, Charles francis. 1953. Audiovisual Materials their Nature and Use. New York: Harper and Brothers Company.

Zulfadland. 2013. Improving grade $X$ Students Achievement in Writing Narrative Paragraph Through Animation Movie. (online) Retrieve from (http://www.jurnal.unimed.ac.id). Accesed on January 2015. 